\title{
中野家住宅茶室にみる近代の工匠北村傳兵衛の作事について A STUDY ON THE CONSTRUCTION OF CARPENTER DEMBEI KITAMURA OF THE MODERNIZATION IN THE NAKANO FAMILY HOUSING TEAROOM
}

\author{
有住侑子*，藤田勝也** \\ Yuko ARISUMI and Masaya FUJITA
}

\begin{abstract}
The purpose of this research is in the actual condition elucidation of construction by carpenter Dembei Kitamura of Kyoto. In this paper, the Nakano family residence which carries out the whereabouts to Nagaokakyo-shi, Kyoto is taken up in order to clarify a part of construction by Dembei in detail.

It analyzed centering on the "estimate" of the "Nakano family old document" about the actual condition of Dembei's construction in the tearoom of the Nakano family residence, and a material plan. Dembei planned the detailed material plan from the estimated stage, and added change suitably, and expected it to construction implementation.
\end{abstract}

Keywords : Dembei Kitamura, Nakano family residence, tearoom, modernization, carpenter 北村傳兵衛，中野家住宅，茶室，近代，工匠

\section{1. はじめに}

\section{1-1 研究の背景・目的・方法}

本研究の目的は、京都の工匠北村傳兵衛（明治 27 年生〜昭和 60 年没）（以下、傳兵衛と略称する）による作事の実態解明にある。

北村家は代々両替商・油商を営み、安永から天明年間頃に四代目傳 兵衛が大工職に転向、昭和 60 年まで家業として継承された。屋号「房 屋」で、代々「傳兵衛」を襲名した。遡って北村家は元禄頃より東木 屋町通り（現木屋町通り）松原上る美濃屋町に居住し、工匠傳兵衛も ここを本拠に活動した。現在も大傳月軒として居宅は良好に遺る。

傳兵衛が作事に関わった建物は京都に 100 棟近くもあったとされ るが 1)、詳細はほとんじ知られていない。管見では中村昌生氏が近代 の工匠の一人として傳兵衛を取り上げ ${ }^{11}$ 、そのほかにも数寄屋の大工、 町屋の大工として断片的に紹介されることはこれまでもあったが、活 動の実態はなお不明な点が多いのが実情である注1)。

本稿では京都府長岡京市に所在する中野家住宅注2)をとりあげ、傳 兵衛による作事の一端を詳細に明らかにする。中野家には傳兵衛の作 事関係史料である『中野家文書』(中野家所蔵) 注 3) が今日まで伝わ り、またこの作事による建物が良好に現存するからである。

筆者等はこれまでこの『中野家文書』も参看しつつ、傳兵衛の活動 実態について概要把握を試みた ${ }^{2)}$ 。本稿では同史料の中でとくに茶室 「皎庵」の用材計画に関する史料に注目し、その詳細な分析・検討を 通して傳兵衛の作事の一端を明らかにしたい。

\section{1-2 中野家ならびに中野家住宅・茶室「盿庵」の概要注 4}

中野家住宅は長岡京市の南部東方、調子地区の旧西国街道沿いに 所在する (図 1)。昭和 24 年の長岡町成立以前は新神足村、さらに
それ以前は調子村に属し、街道を村境に友岡村と接する地域にあた る。調子村は近衛家の随身調子氏の本拠地で、同氏が代々知行して きたことにその名の由来があり、江戸時代の村高 217 石余で、正親 町家領と調子筑後知行からなっていた。

中野家が位置する当地域は街道沿いの街村であって、近在農村に おける商品経済の普及・発展にともなって、茶屋町が 17 世紀前半頃 に形成され、街道北は茶屋北町として友岡、街道南は茶屋南町と呼 ばれ、調子に属していた。すなわち友岡、調子の 2 村の出屋敷とし て形成された町場であった。茶屋南町は、『京都御役所向大概覚書』 注5)に記す調子村の 6 字地のうち「大縄」にあたる。

中野家の当地での居住開始時期は明らかではないが、古くは街道 沿いにたつ茶屋として商いに従事していたものと考えられる。代々 金兵衛を名乗っていたといい、史料上の「金兵衛」は、『調子家田畑 居屋敷定納改帳』注 6) に名請人として見えるのが早い。現当主康男 氏 (大正 10 年 $<1921>\sim)$ ) 曾祖父金兵衛は酒造りも兼業し苗字帯 刀を許されたという。祖父米造、その次男時太郎はともに新神足村 の村長をつとめ、米造の長男で現当主の父種一郎（明治 9 年 $<1876$ $>$ 昭和 49 年 $<1974>$ ） は、政財界に広く活躍した実業家であり、 昭和 45 年には京都市名誉市民となっている ${ }^{3)}$ 。現在の中野家住宅は 種一郎の生家で、明治 41 年に伏見三栖向町の転居まで居所とし、転 居後は弟時太郎に委䄈るが、戦後すぐに五男康男氏の新居として整 備され現在に至っている。

中野家住宅は調子地区の旧西国街道沿いの一画を占める（図 1 参 照)。主屋・土蔵は江戸末期の造営とみられるが、昭和 23 年から 26 年にかけて傳兵衛がそれらに改修を施した注7)。当家には前記した通

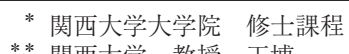

** 関西大学 教授.工博
Graduate Student, Graduate School of Engineering, Kansai Univ.

Prof., Kansai University, Dr. Eng. 


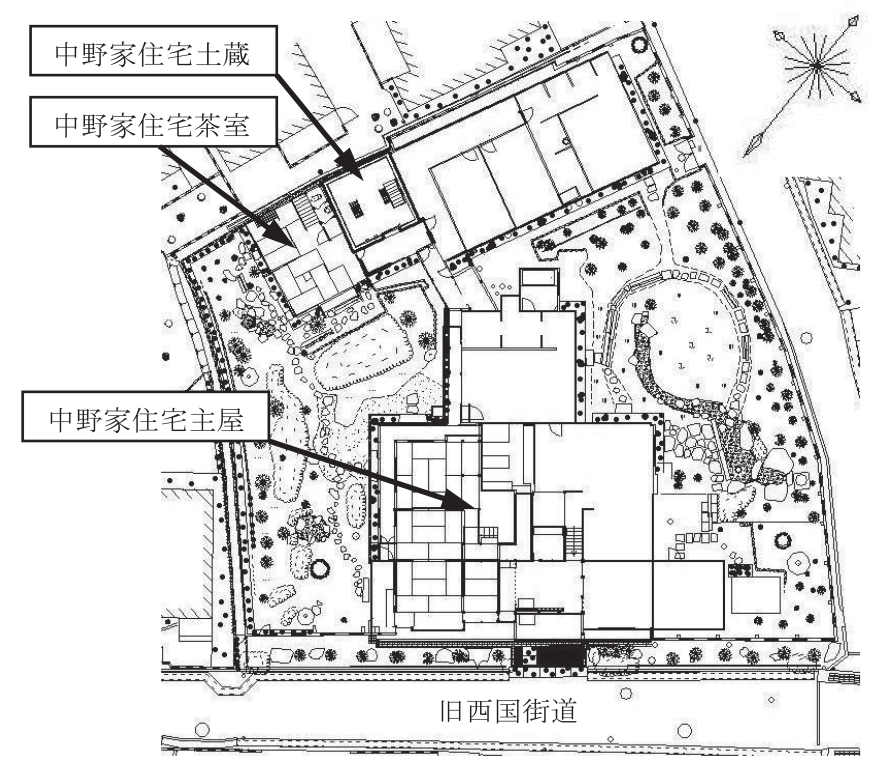

図 1 中野家住宅の配置平面図（田中美知恵作図・調整、露地 - 庭 園は長岡京市教育委員会の提供図面による)

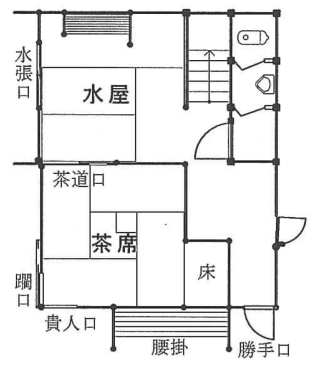

一階

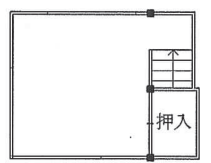

二階

図 2 中野家住宅茶室の平面図（田中美知恵作図）

り傳兵衛直筆の図面や写真など、このときの作事関係史料『中野家 文書』が今に伝えられている。

茶室「晈庵」は、敷地奥の離れの一角にある。当初は、敷地南東 面の塀に沿って、南方から納屋 2 棟と土蔵が並列していた。離れは 大正 10 年以前に、土蔵に接する位置に増築された建物であって、茶 室は昭和 23 年にはじまる傳兵衛による当家の増改築の一環として 新設された（図 2)。着工は昭和 26 年 5 月、竣工は同年 8 月。その 後 10〜11月中頃まで露地の造営がなされている。この増改築は、二 階建てで前面に平屋を附属させていた離れの平屋部分を取り壊し、 その位置に新たに茶席を設けるとともに、二階建て部分の階下（直 下）は、軸組をそのまま残しつつ内部を水屋に改造するというもの で、さらに二階の四畳半は子供室に改造された。近年では茶席が平 成 20 年に補修をうけている注8)。

\section{2. 用材に関する『中野家文書』の史料}

『中野家文書』は全 59 点である。このうち下記の 3 点が用材計画 に関する史料として挙げられる。

『中野邸茶席材料見積書』（以下、『見積書』と略記）写真 1

『調子中野邸茶席用材調書 (仮称)』(以下、『用材調書』之略記)

写真 2

『中野邸數咅屋設計図』内の「茶席木割」

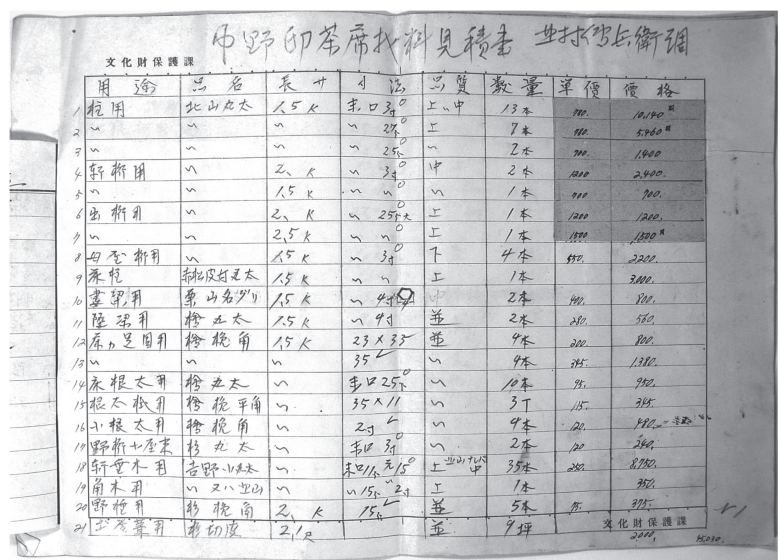

写真 1 『中野邸茶席材料見積書』(一部)

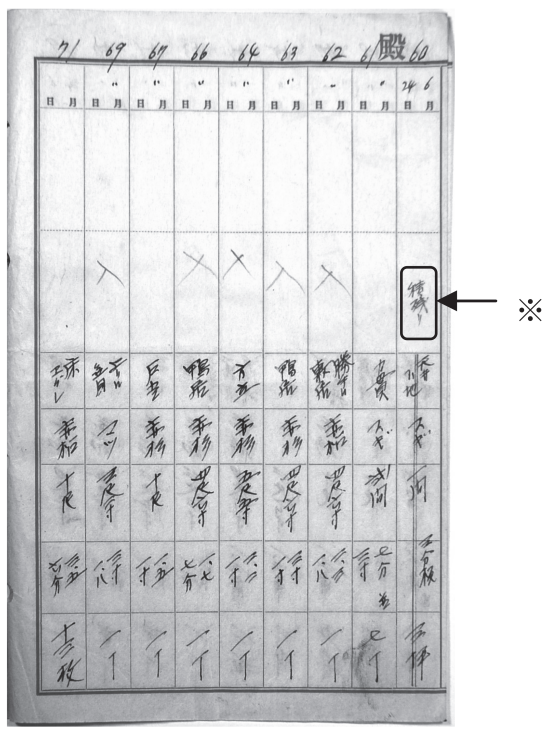

写真 2 『調子中野邸茶席用材調書』(一部)

注 : ※部分「積残リ」は、二重訂正線とともに朱で記される。

いずれも茶室に関するものである。ただし『中野邸數妾屋設計図』 は収載図面や「茶席木割」に記される用材の内容を現状の茶室と比較 すると異同が多いことから、計画のごく初期段階で作成された草案 に近いものかと考えられ、また用材計画の検討に十分なデータを提 供しないこともあり、本稿では対象からはずし、実施計画により近 い『見積書』と『用材調書』の 2 点について詳細な検討を加えること とする。

\section{2-1 史料の概要}

『見積書』は、左上部・右下部に「文化財保護課」とある朱の買線 入りの用紙に、茶室の用材の用途・品名・長さ・法注 ${ }^{9)} \cdot$ 品質・数 量・単価・価格注 10$)$ を鉛筆で記した史料である。左端欄外に通し番号 を付し、計 114 項目を計 6 枚に記載する。その 1 枚目の上部欄外に「中 野邸茶席材料見積書 北村傳兵衛調」と表題を記す（写真 1 )。さら に「中野邸茶席用材追記」と表記した用紙 1 枚をこの上に重ねて綴じ る。これは「京都府文化財保護課用紙」と中央に朱で銘記した縦書き、 横置きの用紙で、これを二つ折りにして横書きでさらに 8 項目を記載 する。計 7 枚、通し番号は $1 \sim 122$ までの、計 122 項目である。

いっぽう『用材調書』も朱の羁線枠入りの用紙だが、横置きの用 紙を二つ折りにして計 4 丁を紙紐で綴じる。縦書き、鉛筆ではなく 
表 1 『中野邸茶席材料見積書』の記載内容

\begin{tabular}{|c|c|c|c|c|c|c|c|c|c|}
\hline 号 & 用途 & 品名 & 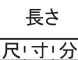 & 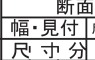 & $\begin{array}{l}\text { 盛見見这 } \\
\text { 分分 }\end{array}$ & 品質 & 数量 & $\begin{array}{l}\text { 単価 } \\
\text { (円) }\end{array}$ & $\begin{array}{l}\text { 価格 } \\
\text { (円) }\end{array}$ \\
\hline & 柱用 & 北山丸太 & & 䒠口3 & & 上-中 & 13 本 & 780 & 10,140 \\
\hline & 柱用 & 北山丸太 & $9_{1}^{\prime}$ & 末口2寸 & & 上 & 7本 & 780 & 5,460 \\
\hline & 柱用 & 北山丸太 & 9 & 末口2寸 & & 上 & 2 本 & 700 & 1,400 \\
\hline & 軒桁用 & 北山丸太 & $12 !$ & 末口3 & & 中 & 2 本 & 1,200 & 2,400 \\
\hline & 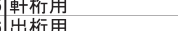 & 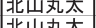 & $\begin{array}{r:}9 ! \\
12 !\end{array}$ & $\begin{array}{l}\text { 梠口 } \\
\text { 末 }\end{array}$ & & 中 & 1 本 & 700 & $\begin{array}{r}700 \\
200\end{array}$ \\
\hline & 出韭用 & $\begin{array}{l}\text { 北山むれ丸 } \\
\text { 北山丸太 }\end{array}$ & $\begin{array}{l}12 ! \\
15 ! \\
15\end{array}$ & 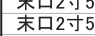 & $\begin{array}{l}5 \text { 年分大 } \\
\text { 5 }\end{array}$ & $\mid \frac{\mathrm{r}}{\mathrm{t}}$ & $\begin{array}{l}1 \text { 本 } \\
1 \text { 本 }\end{array}$ & $\begin{array}{l}1,200 \\
1,500\end{array}$ & $\begin{array}{l}1,200 \\
1,500\end{array}$ \\
\hline & 每屋桁用 & 北山丸太 & $9 !$ & 末日3 & & 穴 & 4 本 & 550 & \\
\hline & 床柱 & 峦松皮付 & $9 i$ & 末口3 & & 上 & 1 本 & & 3,000 \\
\hline 10 & 妻梁用 & |栗山名グ & $9_{1}^{1}$ & 末口4 & & & 2 本 & 400 & 800 \\
\hline 11 & $\mid$ 陸梁用 & 檜丸太 & $9 !$ & 末口4 & & 並 & 2 本 & 280 & 560 \\
\hline & 床力足固用 & 檜挽角 & $9 !$ & $\mid \begin{array}{ll}2 & 3 \\
2 & 2\end{array}$ & \begin{tabular}{|l|l|}
$!$ \\
\end{tabular} & 普 & 4 本 & 200 & 800 \\
\hline $\begin{array}{r}13 \\
14\end{array}$ & $\begin{array}{l}\text { 麻力足固用 } \\
\end{array}$ & 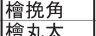 & $\begin{array}{l}9 ! \\
9 ! \\
9 !\end{array}$ & $\begin{array}{l}\text { 3寸5分 } \\
\text { 本口讨 }\end{array}$ & & 普 & $\begin{array}{r}4 \text { 本 } \\
10 \text { 本 }\end{array}$ & $\begin{array}{r}345 \\
95\end{array}$ & $\begin{array}{r}1,380 \\
950\end{array}$ \\
\hline 15 & 根太掛用 & 檜挽苹角 & $9 !$ & 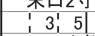 & & 业亚 & $\begin{array}{l}10 \text { 我 } \\
3 \mathrm{~T}\end{array}$ & $\begin{array}{r}95 \\
115\end{array}$ & $\begin{array}{l}340 \\
345\end{array}$ \\
\hline & 小根太用 & 檜挽角 & $9 !$ & 2寸角 & & 亚 & 4 本 & 120 & 480 \\
\hline 17 & |野析小屋束 & 杉丸丸 & $99_{1}^{1}$ & 末口3 & & 並 & 2 本 & 120 & 240 \\
\hline 18 & 軒垂木用 & 诘野小丸 & $9 !$ & $\begin{array}{l}\text { 䄅口讨 } 1 \\
\text { 元口1寸 }\end{array}$ & & \begin{tabular}{|l} 
上北山゙ \\
ナレバ中
\end{tabular} & 35 本 & 250 & 8,750 \\
\hline 19 & 角木用 & $\begin{array}{l}\text { 䓀野小丸丸 } \\
\text { 出八北 }\end{array}$ & $9 !$ & $\begin{array}{c}\text { 末口1寸 } 5 \text { s } \\
\text { 口2 }\end{array}$ & 分、元 & 上 & 1 本 & & 350 \\
\hline 20 & 野棰用 & 嵝挽角 & $12:$ & 1寸5分 & & 並 & 5 本 & 75 & 375 \\
\hline & \begin{tabular}{|c|} 
居葺用 \\
\end{tabular} & 杉切皮 & $2 i 1 i$ & & & 並 & 9 坪 & & 2,000 \\
\hline & 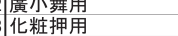 & 奕杉 & $\begin{array}{l}12 i \\
12 ! \\
12\end{array}$ & $\begin{array}{l}2 i \\
2 ! \\
2 ! \\
5\end{array}$ & & 㥶 & $\begin{array}{r}4 \text { 枚 } \\
30 \text { 枚 }\end{array}$ & $\begin{array}{r}396 \\
33\end{array}$ & $\begin{array}{l}1,584 \\
990\end{array}$ \\
\hline & 野地及壁貫用 & 杉 & $12 !$ & $3 !$ & & 㫫 & 35 枚 & 34 & $1,761.90$ \\
\hline 25 & 可骂板用 & 赤杉 & $12 !$ & $: 1: 2$ & & 上 & 2 本 & 100 & 200 \\
\hline $\begin{array}{l}26 \\
27\end{array}$ & 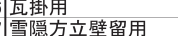 & 榇标 & 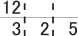 & 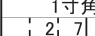 & & 普: & $\begin{array}{l}6 \text { 本 } \\
\text { 3 T }\end{array}$ & $\begin{array}{r}33 \\
190 \\
\end{array}$ & $\begin{array}{l}198 \\
570\end{array}$ \\
\hline & 雪隠方立壁箇用隌 & 尔杉 & $\begin{array}{l}x_{1}<1 \\
6 ! \\
6 !\end{array}$ & $\begin{array}{l}2 ! \\
2 ! \\
\end{array}$ & & \begin{tabular}{|l} 
上丨ハハ柾 \\
\end{tabular} & $1 \mathrm{~T}$ & 190 & $\begin{array}{l}510 \\
356\end{array}$ \\
\hline & 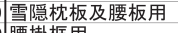 & 黑部 & $\begin{array}{l:l}3 & 5 \\
3 & 5\end{array}$ & & & 枉 & 6 枚 & 500 & 3,000 \\
\hline 30 & 腰挂忹用 & 赤松 & $\begin{array}{l}9 ! \\
9\end{array}$ & $2: 6$ & \begin{tabular}{|lll}
1 & & \\
\end{tabular} & 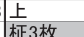 & $1 \mathrm{~T}$ & & 680 \\
\hline 31 & 腰掛クレ用 & 赤松 & $9 !$ & $3 !$ & & 秝极 & 6 枚 & 360 & 2,160 \\
\hline 32 & 床板用 & 桂标 & $\begin{array}{l:}6 \\
6\end{array}$ & $8 !$ & & 䗒 & 5 坪 & 530 & 2,650 \\
\hline 33 & 畫院中敷鴨居居 & \begin{tabular}{|l} 
赤杉 \\
新
\end{tabular} & $\begin{array}{lll}5 & 2 ! \\
5 & 2\end{array}$ & 3 & 11 & 卡ソバ柾 & $2 \mathrm{~T}$ & 396 & 792 \\
\hline & $\mid$ & 黑部 & 5,2 & $9_{1}^{1}$ & & 中 圭 & 1 枚 & & 800 \\
\hline & 貴人口敷用 & 赤松 & $\begin{array}{rl}4 ! & 6 ! \\
4 & 6 !\end{array}$ & i 31 & & 柾 & $1 \mathrm{~T}$ & & 594 \\
\hline 36 & 潰人口゙鴨居用 & 赫㭲 & $\begin{array}{l}4 ! \\
6 ! \\
6 !\end{array}$ & $\begin{array}{l}2 ! \\
2 ! \\
2 !\end{array}$ & 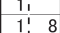 & 座柾杫 & $1 \mathrm{~T}$ & & 280 \\
\hline 38 & 关リ中敷鴨居 & 赤杉 & $6:$ & 218 & $\begin{array}{l}1 \\
1 \\
\end{array}$ & 上ソバ柾 & $2 \mathrm{~T}$ & 296 & 592 \\
\hline 39 & 二ジリ方立用 & 赤杉 & $2: 4$ & $2: 3$ & : & 上ソバ柾 & $1 \mathrm{~T}$ & & 95 \\
\hline & =ジリ戸當り用 & 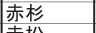 & $4: 3 i$ & $1: 4$ & : & 上ソバ柾 & $2 \mathrm{~T}$ & 112 & 224 \\
\hline 41 & =ジリハサシミ敷用 & 赤松 & $\begin{array}{ll}4 i & 7 i \\
4\end{array}$ & $\begin{array}{ll}1 i & 7 \\
1 & 1\end{array}$ & $i$ & 柾 & $1 \mathrm{~T}$ & & 120 \\
\hline $\begin{array}{r}42 \\
43\end{array}$ & $\begin{array}{l}\text { ニシリハサシ鴨居 } \\
\text { ニジリ連子賁 }\end{array}$ & $\begin{array}{l}\text { 赤杉 } \\
\text { 杉 }\end{array}$ & $\begin{array}{l}44_{1} \\
6 ! \\
6 !\end{array}$ & $\begin{array}{rl}1 & 7 \\
1 & 8\end{array}$ & 1 & $\mid$ & $\begin{array}{l}1 \mathrm{~T} \\
1 \text { 本 }\end{array}$ & & $\begin{array}{r}120 \\
53\end{array}$ \\
\hline & 二ジリ連子底板 & 筡杉 & $4: 7$ & $1 ;$ & $1:$ & 平柾 & 1 本 & & 30 \\
\hline 45 & 茶道口敷用 & 赤松 & $9:$ & $3 !$ & $1 i$ & 平柾 & $1 \mathrm{~T}$ & & 1,080 \\
\hline & 茶道口鴨 & 赤杉 & $4 i 6 i$ & $2 i 7$ & $1 i$ & |ソバ柾 & $1 \mathrm{~T}$ & & 270 \\
\hline $\begin{array}{r}47 \\
48\end{array}$ & $\begin{array}{l}\text { 茶道口方立用 } \\
\text { 潼猢用 }\end{array}$ & 赤杉 & $\begin{array}{l}5 ! \\
5 ! 1 ! \\
4 !\end{array}$ & 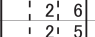 & \begin{tabular}{|l|l}
$1 !$ \\
11 \\
11
\end{tabular} & | & $1 \mathrm{~T}$ & & $\begin{array}{l}345 \\
250\end{array}$ \\
\hline & 床产敷用 & 赤松 & $\begin{array}{ll}4 & 7 \\
4 & 7\end{array}$ & $\begin{array}{ll}1 & 5\end{array}$ & $1_{i}^{i}$ & 位 & 1 本 & & 270 \\
\hline & 床音敷 & 赤松 & $5 ! 2 !$ & $: 1: 1$ & $1 ;$ & ソバ柾 & 2 本 & 240 & 480 \\
\hline 51 & 床咅敷用 & 赤松 & 2i $5 i$ & $\begin{array}{ccc}11 \\
1\end{array}$ & $\begin{array}{ll}1: \\
1:\end{array}$ & ソバ柾 & 2 本 & 60 & 120 \\
\hline 52 & 床景敷用 & 赤松 & 4,6, & 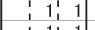 & $1 !$ & ハバ柾 & 1本 & & 198 \\
\hline & $\mid$ & 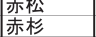 & $\begin{array}{ll}3 ! & 2 ! \\
4 & 6\end{array}$ & 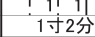 & 穴角 & 柾 柾 & $\begin{array}{l}1 \text { 本 } \\
2 \text { 本 }\end{array}$ & 145 & $\begin{array}{l}130 \\
290\end{array}$ \\
\hline & 床天井迴用 & 赤杉 & $2 ! 6 !$ & 1寸2分 & & 柾 & 2 本 & 75 & 150 \\
\hline & 床天井板用 & 赤杉 & $4 ! 4$ & 巾2R5 & & 中圭 & 1 枚 & & 3,500 \\
\hline 57 & 席天井迴用 & 赤杉 & 9 & 讨3分 & 分角 & 柾 & 5 本 & 330 & 1,650 \\
\hline & 席天井等用 & 赤杉 & $\begin{array}{r:}9 \\
12\end{array}$ & $\begin{array}{l}: 113 \mid \\
1+3 \text { 分 }\end{array}$ & 盗角 & 柾 & $\begin{array}{l}4 \text { 本 } \\
8 \text { 本 }\end{array}$ & $\begin{array}{r}286 \\
50\end{array}$ & $\begin{array}{r}1,144 \\
400\end{array}$ \\
\hline & 席天卉下地用 & 杉 & $6:$ & 3分板 & & 普 & $\begin{array}{l}0 \text { 坪 } \\
\end{array}$ & 330 & 990 \\
\hline 61 & 力貫用 & 杉 & 12 & 31 & & 亚 & $7 \mathrm{~T}$ & 70 & 490 \\
\hline & 勝手入口敷月 & 赤松 & $4: 6$ & $2: 3$ & $1 !$ & 中 & $1 \mathrm{~T}$ & & 414 \\
\hline 63 & 勝手入口鴨居用 & 赤杉 & $4 ! 6 !$ & $3 !$ & $1 ;$ & 中 & $1 \mathrm{~T}$ & & 300 \\
\hline & 滕手人口方立章用 & 赫㭲 & $\begin{array}{rl}51 & 51 \\
& 1\end{array}$ & $12 \div 2$ & 11 & 中 & $1 \mathrm{~T}$ & & 290 \\
\hline & 勝手入口挟鴨居用 & 湬杉 & $\begin{array}{ll}4 & 0 \\
41 & 61 \\
1 & 61\end{array}$ & 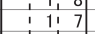 & : & 中 & $1 \mathrm{~T}$ & & $\begin{array}{l}126 \\
120\end{array}$ \\
\hline 67 & 勝手入口戸當り用 & 赤杉 & $9 !$ & $\begin{array}{c:c}1 & 5 \\
\end{array}$ & 11 & 中ンバ柾 & 1本 & & 290 \\
\hline & 引勝手上り口 & 松 & $3 ; 2 ;$ & & $1: 2$ & 中 & 1 枚 & & 792 \\
\hline $\begin{array}{c}69 \\
70\end{array}$ & 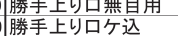 & 松又杉 & $\begin{array}{l}3 ! 2 ! \\
3 ! \\
3 !\end{array}$ & $\begin{array}{l}3 ! \\
5 !\end{array}$ & $\mid \begin{array}{ll}1 & 8 \\
1 & 3 \\
1 & 3\end{array}$ & |中 & $\begin{array}{l}1 \mathrm{~T} \\
1 \text { 枚 }\end{array}$ & & $\begin{array}{l}350 \\
100\end{array}$ \\
\hline 71 & 勝手床力クレ用 & & 9 & $\begin{array}{l:l}5 & 5 \\
1 & 3\end{array}$ & & 中 & 13 枚 & 420 & 5,460 \\
\hline 72 & 勝手袋天板用 & |松 多ヂ & 6 & $1: 1:$ & & 中 & 2 枚 & & 2,000 \\
\hline 73 & 勝手棚板用 & 松 タブヌ & $6:$ & $9 !$ & & 中 & 1 枚 & & 900 \\
\hline 74 | & 勝手 & 松 & 9 & $3 i$ & $1 i$ & 中 & $1 \mathrm{~T}$ & & 1,000 \\
\hline & & 杉 & 6 & $2 i$ & $i_{i}^{\prime}$ & 中 & $1 \mathrm{~T}$ & & 425 \\
\hline 76 & 片シキ & 松 & 9 & $3 !$ & $1_{i}$ & 中 & $1 T$ & & 1,000 \\
\hline 7) & & 杉 & $4: 5$ & 2,7 & $1:$ & 中 & $1 \mathrm{~T}$ & & 270 \\
\hline & 水遗方咅 & 棎 & $\begin{array}{rl}4 i 3 i \\
7 i & 5 i\end{array}$ & $2 ; 7$ & $1 i$ & 虫 & $1 \mathrm{~T}$ & & 270 \\
\hline 80 & 水頲掛芰鴨居 & 林 & $\begin{array}{ll}1 \\
7 & 5 \\
1\end{array}$ & $\begin{array}{lll}1: & 5 \\
1\end{array}$ & 11 & 中 & 1 本 & & 225 \\
\hline 81 & & 松 & $3: 2 !$ & $\begin{array}{l}1 \\
1\end{array}$ & : & 中 & $1 \mathrm{~J}$ & & 112 \\
\hline 82 & 水遺 & 杉 & & $1: 7 !$ & 7 & 中 & $1 \mathrm{~T}$ & & 1,200 \\
\hline & & 松 & $\begin{array}{l:}9_{1}^{\prime} \\
9_{1}\end{array}$ & $\begin{array}{c}3 ! \\
3 \\
21\end{array}$ & \begin{tabular}{|ll}
1 & 8 \\
1 & 8 \\
1 & 8
\end{tabular} & 中 & $1 \mathrm{~T}$ & & $\begin{array}{l}1,000 \\
900\end{array}$ \\
\hline & & 北山太 & $9 i$ & 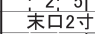 & +2分 & 中 & 1 本 & & 650 \\
\hline & & 杉 & 2 & $\mid \begin{array}{l}\mid \\
\mid\end{array}$ & & 中 & $1 \mathrm{~T}$ & & 86 \\
\hline 87 & 水应 & 杉 & $2 !$ & $\begin{array}{c:c}1 & 5 \\
1 & 5\end{array}$ & $\begin{array}{ll}5 \\
1\end{array}$ & 3中 & $1 \mathrm{~T}$ & & 48 \\
\hline 8 & 水证 & 松 & $\begin{array}{l}9 i \\
1 \\
1^{\prime}\end{array}$ & $\begin{array}{c:c}1 & 8 \\
2 & 8\end{array}$ & \begin{tabular}{|ll}
1 & 2 \\
1 & 5 \\
1 & 5
\end{tabular} & 中 & 1本 & & $\begin{array}{l}430 \\
800\end{array}$ \\
\hline ] & 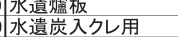 & 松 & $\begin{array}{l}1,5 ! \\
6 !\end{array}$ & $\left|\begin{array}{lll}2 & 0 \\
\hdashline & 3 & 5\end{array}\right|$ & \begin{tabular}{|l|l|} 
& 5 \\
\end{tabular} & F & $\begin{array}{l}1 \text { 本 } \\
\text { 枚 }\end{array}$ & 278 & 8000 \\
\hline 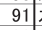 & 水遺 & 檜 & 1,1 & 1寸角 & & 中 & 8 本 & & 220 \\
\hline$=$ & 水遺腰林 & 杉 & $4: 5$ & $1: 4 !$ & $\vdots$ & 中 & 1 枚 & & 1,500 \\
\hline & & 杉 & $2 i$ & $1 i 4 i$ & $\begin{array}{r}i \\
\vdots\end{array}$ & 中桂 & 1 枚 & & 500 \\
\hline & 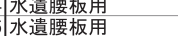 & 棎 & $\begin{array}{l}1,5 ! \\
6 !\end{array}$ & $\left|\begin{array}{ll}1 & 4 ! \\
1 & 81 \\
1 & 81\end{array}\right|$ & $\begin{array}{r}4 \\
\quad 4\end{array}$ & 㞲㭠 & $\begin{array}{l}1 \text { 枚 } \\
1 \text { 枚 }\end{array}$ & & $\begin{array}{l}380 \\
840\end{array}$ \\
\hline & 水遺通り柿棚用 & 杉 & $4: 5$ & \begin{tabular}{|l|l|}
$1_{1}^{\prime}$ & 81 \\
1
\end{tabular} & 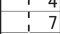 & & $\begin{array}{l}1 \text { 1 } \\
1 \text { 枚 }\end{array}$ & & $\begin{array}{r}840 \\
2,000\end{array}$ \\
\hline & 水遺 & 杉 & $9 !$ & i $9 !$ & 4 & 中脎 & 2 枚 & & 200 \\
\hline $\begin{array}{r}98 \\
99\end{array}$ & 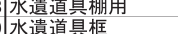 & 杉柊 & $\begin{array}{l}4 i 5 i \\
4 ! \\
4 !\end{array}$ & $\begin{array}{cc}9 i & \\
i & 9\end{array}$ & $\begin{array}{r}12.5 \\
1 \\
1\end{array}$ & 虫 & $\begin{array}{l}1 \\
2 \text { 枚 } \\
2\end{array}$ & 55 & $\begin{array}{l}800 \\
110\end{array}$ \\
\hline
\end{tabular}

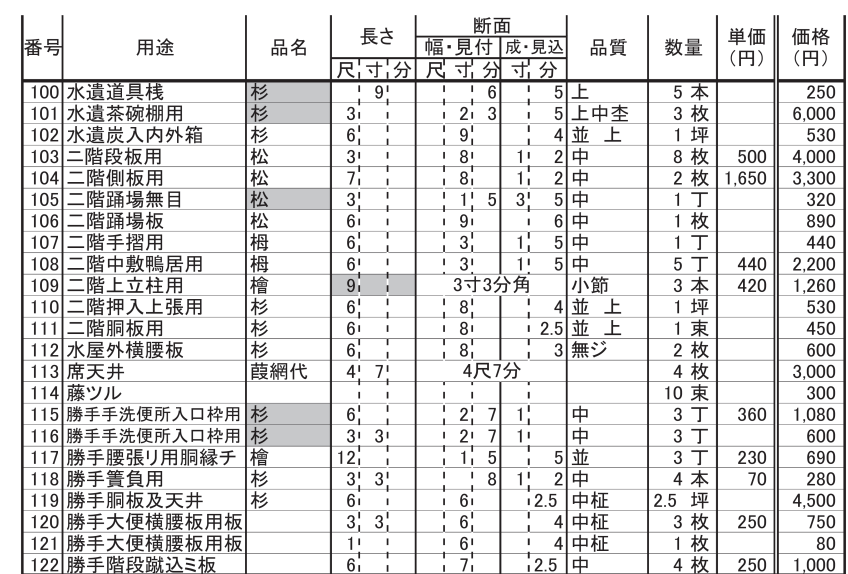

表注 : 史料の長さは、間と尺が混用されているが、尺寸法の表記にした。（表 2 も同様）。網掛け部分は、表 2 と異なる箇所を示す。

インク書きである（写真 2 )。また『見積書』とは筆跡が異なる。上 部欄外に番号を記し、用途・品名・長さ・法注 $\left.{ }^{11}\right) \cdot$ 数量と、一部 の部材には品質を記入する。また欄内上部に日付欄があり多くの用 材に日付も記されるが、す心゙て「6月 24 日」である。また『用材調 書』は紙封筒に収められていた。封筒の表面に「調子 中野邸茶席用 材調書在中 竹 $\square$ 様」( $\square$ は判読不明の文字)、裏面に「昭和二十六年 六月一日 北村傳兵衛」の鉛筆書きがある。

\section{$2-2$ 史料の分析}

『見積書』の鉛筆書きの筆跡は、『中野家文書』の他の史料とも比 較して、傳兵衛自身によるものであると判断される。つまり傳兵衛 が中野家住宅の作事にあたって、見積もり用に作成したのがこの『見 積書』である。

いっぽう前記したように、『用材調書』は傳兵衛とは筆跡が異なる。 上部欄外に記載の番号は『見積書』の通し番号に対応しているが、

『用材調書』には表題がない。また 4 丁裏は番号 65 が最後で以後空 欄としているから最終頁と見なし得るものの、1 丁表が冒頭、番号 23 からはじまるのはやや不審である。番号 22 以前の記載部分が散 逸した可能性をこれは示唆する。

記載内容についてはどうか。『見積書』の計 122 項目のうち 64 項 目を抜粋、記載している (表 $1 、 2$ 参照)。番号が途中で飛び、また 前後に乱れがある。また『用材調書』の内容の一部は『見積書』と 異なる。異なるのは樹種や長さ、断面、数量である（表 $1 、 2$ の網掛 け部分)。そこで『用材調書』は『見積書』の内容に変更を加えて作 成されたものと推測される。

『見積書』と『用材調書』の記載内容の相違点を具体的に検証す る。まず樹種が異なるのは計 11 項目挙げられる（表 3)。番号 65 挟 敷居や 72 袋天板以外は、『見積書』に比べ『用材調書』の樹種の方 がより詳細である。番号 72 袋天板は『見積書』では複数の樹種を挙 げているが、『用材調書』ではその中から杤に特定していることがわ かる。長さが異なるものをまとめたのが表 4 である。番号 $32 \cdot 37$ ・ 38 の 3 項目を除いて、『見積書』ではすべて 9 尺だが『用材調書』で はすべて 10 尺である。さらに大きさが異なるものでは、番号 86 空中 敷居が『見積書』では見込み 8 分、対して『用材調書』では 7 分であ る (表 $1 、 2$ 参照)。さらにまた数量についてみると、番号 31 腰掛榑 板が『見積書』では柾目 3 枚と板目 3 枚の計 6 枚に対し、『用材調書』 
では柾目 3 枚で（表 $1 、 2$ 参照）『用材調書』は板目 3 枚分少ない。 かように『用材調書』の方が『見積書』より内容が概して一層具体 的である。番号 60 、天井下地は余白に「積残リ」と記し（写真 2 の ※参照)、記載内容を朱の二重線で抹消する (表 2 参照)。また一部 余白に「入」や「一本」という記載もある (表 2 の備考欄参照)。史 料の品名や長さ・断面・数量が黒インク書きであるのに対し、「入」

表 2 『調子中野邸茶席用材調書』の記載内容

\begin{tabular}{|c|c|c|c|c|c|c|c|c|c|}
\hline 番号 & 用途 & 品名 & $\begin{array}{r}\text { 長さ } \\
\text { 尺i寸 } \\
\end{array}$ & \begin{tabular}{c}
\multicolumn{2}{c}{ 断面 } \\
幅·見付 \\
尺i寸分 \\
\end{tabular} & $\frac{\text { 成-見这 }}{\text { 寸分 }}$ & 品質 & 数量 & 日付 & 備考 \\
\hline 23 & 化粧押 & 杉 & $12 !$ & $\begin{array}{l}7,5 \\
12,5\end{array}$ & & & 30 枚 & 6月24日 & \\
\hline 24 & 野地壁貫 & 杉 & 12 & $3 !$ & 4 & & 35 枚 & 6月24日 & \\
\hline 25 & 品板 & 赤杉 & $12 i$ & $\begin{array}{ll}1 & 2 \\
11 & 2\end{array}$ & $\begin{array}{ll}1 & 6 \\
\end{array}$ & & 2 枚 & 6月24日 & \\
\hline 30 & 腰掛 框 & 赤松 & $10 !$ & $\begin{array}{ll}2 & 6\end{array}$ & $1: 3$ & & $1 \mathrm{~T}$ & 6月24日 & \\
\hline 31 & ログレ & 赤松 & 10 & \begin{tabular}{|l|l|}
1 & 1 \\
1 & 31 \\
1
\end{tabular} & $\begin{array}{ll}1 & 6 \\
1 & 6\end{array}$ & 柾 & 3 枚 & 6月24日 & \\
\hline 32 & 床板 & スギ & 10 & $\begin{array}{l}15 \\
\end{array}$ & 81 & & 5 坪 & & \\
\hline 33 & 書院中敷鴨居 & 赤杉 & $5: 2$ & $3 i$ & $1 ;$ & & $2 T$ & 6月24日 & 1本 \\
\hline 34 & 枕板 & 黒部 & & $\begin{array}{lll}1 & 1 & 3 \\
1 & 1 & 0\end{array}$ & $9 i$ & & 1 枚 & 6 月 24 日 & \\
\hline 35 & 貴人口敷居 & 赤松 & $4: 6$ & $3 !$ & $1: 8$ & & $1 \mathrm{~T}$ & & 入 \\
\hline 36 & 鴨居 & 赤杉 & $4: 6$ & $\begin{array}{l}2: 7 \\
1\end{array}$ & 11 & & $1 \mathrm{~T}$ & 6月24日 & \\
\hline 37 & ニジリ敷居 & 赤松 & 10 & $\begin{array}{lll}1 & 1 \\
1 & 2 & 5 \\
\end{array}$ & $\begin{array}{ll}1: & 8\end{array}$ & & $1 \mathrm{~T}$ & 6月24日 & \\
\hline 38 & 中敷鴨居 & 赤杉 & $10 !$ & $2: 8$ & 8 & & 2 枚 & 6月24日 & 1本 \\
\hline 39 & 方立 & 赤杉 & $\begin{array}{ll}2 & 4\end{array}$ & $\begin{array}{lll}2 & 3\end{array}$ & 8 & & $1 \mathrm{~T}$ & 6月24日 & \\
\hline 42 & ニジリハサミ鴨居 & 赤杉 & $4: 7$ & $\begin{array}{lll} & 1: 7 \\
1 & 7\end{array}$ & $\begin{array}{ll}1 & 7 \\
1\end{array}$ & & 1 枚 & 6月24日 & \\
\hline 45 & 茶道口敷 & 赤松 & 10 & $3 !$ & 118 & & $1 \mathrm{~T}$ & 6月24日 & 入 \\
\hline 46 & 鴨居 & 赤杉 & $\begin{array}{lll}4 & 6\end{array}$ & 217 & $1 i$ & & $1 \mathrm{~T}$ & 6月24日 & 入 \\
\hline 47 & 方立 & 赤杉 & $5: 3$ & $2: 6$ & $1 !$ & & $1 \mathrm{~T}$ & 6月24日 & $\lambda$ \\
\hline 48 & 床落掛 & 赤杉 & $\begin{array}{ll}4 & 7\end{array}$ & $\begin{array}{ll}21 & 5\end{array}$ & 11 & & $1 \mathrm{~T}$ & 6月24日 & 入 \\
\hline 49 & 寄シキ & 赤松 & $4: 7$ & $1: 5$ & $\begin{array}{ll}1 & 8 \\
1 & 0\end{array}$ & & $1 \mathrm{~T}$ & 6月24日 & \\
\hline 50 & 寄シキ & 赤松 & $5 \div 2$ & 1 1: 1 & 118 & & $2 \mathrm{~T}$ & 6 月24日 & \\
\hline 51 & 奇シキ & 赤松 & 25 & $\begin{array}{ll}1 & 1\end{array}$ & $\begin{array}{ll}1 & 8 \\
1 & 8\end{array}$ & & $2 T$ & 6月24日 & \\
\hline 53 & 寄シキ & 赤松 & $\begin{array}{ll}3 & 2\end{array}$ & {$\left[\begin{array}{lll}1 & 1\end{array}\right.$} & $1 \div 8$ & & $1 \mathrm{~T}$ & 6月24日 & \\
\hline 54 & 床天井廻リ & 赤杉 & $4: 6$ & 1寸2分 & 角 & & 2本 & 6月24日 & \\
\hline 55 & 床天井廻リ & 赤杉 & $\begin{array}{lll}2 & 6\end{array}$ & 1寸2分 & 角 & & 2 本 & 6月24日 & \\
\hline 57 & 床天井建り & 赤杉 & $10 !$ & 1寸3分 & & & 5 本 & 6月24日 & \\
\hline 58 & 床天井笔 & 赤杉 & 10 & $\begin{array}{lll}i & 1 i & 3\end{array} \mid$ & $\begin{array}{ll}1 i & 1\end{array}$ & & 4 本 & 6月24日 & \\
\hline 59 & 天井下地 & スギ & $12 !$ & 1寸3分 & 角 & 並 & 8 本 & 6月24日 & \\
\hline 60 & 全井下地 & Z垂 & 01 & 可分板 & & & 3 坪 & 6月24日 & 積残り \\
\hline 61 & 力貫 & スギ & $12 !$ & $3 i$ & $\begin{array}{l}i 7 \\
\end{array}$ & 並 & $7 \mathrm{~T}$ & 6月24日 & \\
\hline 62 & 勝手口敷居 & 赤松 & $4: 6$ & $\begin{array}{lll}2 & 3\end{array}$ & $\begin{array}{ll}1 & 8 \\
\end{array}$ & & $1 \mathrm{~T}$ & 6月24日 & 入 \\
\hline 63 & 鴨居 & 赤杉 & $4 ! 6$ & $3 !$ & 11 & & $1 \mathrm{~T}$ & 6月24日 & $\lambda$ \\
\hline 64 & 方立 & 赤杉 & $5: 5$ & $\begin{array}{ll}2: & 2\end{array}$ & & & $1 \mathrm{~T}$ & 6月24日 & $\hat{\lambda}$ \\
\hline 66 & 鴨扂 & 赤杉 & $4: 6$ & $1: 7$ & 7 & & $1 \mathrm{~T}$ & 6月24日 & $\lambda$ \\
\hline 67 & 戸當 & 赤杉 & 10 & $\begin{array}{ll}1 & 5\end{array}$ & $1:$ & & $1 \mathrm{~T}$ & 6月24日 & \\
\hline 69 & 上り口無目 & マッ & $3: 2$ & $3 !$ & $\begin{array}{l:l}1 & 8 \\
\end{array}$ & & $1 \mathrm{~T}$ & 6月24日 & $\lambda$ \\
\hline 71 & 床ログレ & 赤松 & 10 & $\begin{array}{ll}1 & 5 \\
& 3\end{array}$ & $\begin{array}{ll}1 & 6 \\
1 & \end{array}$ & & 13 枚 & & \\
\hline 72 & 袋天板 & トチ & $6:$ & $\begin{array}{lll}1 & 1 & 1\end{array}$ & $\begin{array}{ll}1 & 9 \\
1\end{array}$ & & 2 枚 & 6月24日 & \\
\hline 74 & 押入敷 & マツ & $10 !$ & 3 & $1: 8$ & & $1 \mathrm{~T}$ & 6月24日 & 入 \\
\hline 75 & 敷居 & スギ & 6 & $\begin{array}{r}17 \\
1 \quad 7 \\
\end{array}$ & $\begin{array}{ll}1 & 2\end{array}$ & & $1 \mathrm{~T}$ & 6月24日 & 入 \\
\hline 76 & 水遺敷居 & マツ & $10 !$ & $3 !$ & $\begin{array}{ll}1 & 8 \\
\end{array}$ & & $1 \mathrm{~T}$ & 6月24日 & \\
\hline 77 & 鴨呞 & スギ & $\begin{array}{lll}4 & 5 \\
\end{array}$ & 27 & 11 & & $1 \mathrm{~T}$ & 6月24日 & $\lambda$ \\
\hline 78 & 方立 & スギ & $\begin{array}{l:l}4 & 3 \\
4\end{array}$ & $\left|\begin{array}{ll}1 & 1 \\
2 & 7\end{array}\right|$ & $1 i$ & & $1 \mathrm{~T}$ & 6月24日 & $\hat{\lambda}$ \\
\hline 85 & 中柱 & 北山 & 10 & 丸太末口 & 2寸2分 & & 1 本 & 6月24日 & \\
\hline 86 & 空中敷 & 赤杉 & 2 & 217 & 17 & & $1 \mathrm{~T}$ & 6月24日 & \\
\hline 87 & 鴨居 & & $2 !$ & $\begin{array}{lll}1: & 5 \\
1 & 1\end{array}$ & $\begin{array}{l}1 \quad 8 \\
1\end{array}$ & & $1 \mathrm{~T}$ & 6 月24日 & \\
\hline 90 & 炭入クレ & 赤松 & $6 !$ & 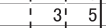 & $\begin{array}{ll}0 \\
1\end{array}$ & & 3 枚 & 6月24日 & \\
\hline 92 & 腰板 & スギ & $\begin{array}{l:l}4 & 5 \\
\end{array}$ & $\begin{array}{ll}1 & 4 \\
11 & 4\end{array}$ & $\begin{array}{ll}1 & 4\end{array}$ & & 1 枚 & 6 月 24 日 & \\
\hline 93 & 腰板 & スギ & $2 !$ & 1! 4 & $\begin{array}{ll}1 & 4\end{array}$ & & 1 枚 & 6月24日 & \\
\hline 94 & 腰板 & スギ & 115 & 114 & $\begin{array}{r}1 \\
1\end{array}$ & & 1 枚 & 6 月24日 & \\
\hline 98 & 道具柵用 & 赤杉 & $4: 5$ & $9_{1}^{1}$ & 2.5 & & 1 枚 & 6月24日 & \\
\hline 100 & 道具柵サン & 赤杉 & $\begin{array}{l}9 \\
1\end{array}$ & $\begin{array}{ll}6 & 6\end{array}$ & $\begin{array}{l}1 \\
1 \quad 5 \\
\end{array}$ & & 5 枚 & 6月24日 & \\
\hline 101 & 茶碗柵用 & 赤杉 & $3 i$ & $\begin{array}{lll} & 2 & 3 \\
\end{array}$ & 5 & & 3 枚 & 6月24日 & \\
\hline 103 & 二階段板 & マッ & $3 !$ & $\begin{array}{ll} & 8 \\
\end{array}$ & $\begin{array}{l:l}1 & 2\end{array}$ & & 8 枚 & 6月24日 & \\
\hline 104 & 側板 & マッ & 71 & 81 & $1: 2$ & & 2 枚 & 6月24日 & \\
\hline 105 & 踊場無目 & 赤松 & $3 i$ & $\begin{array}{l:l}1 & 5\end{array}$ & $\begin{array}{l:l}3 & 5\end{array}$ & & $1 \mathrm{~T}$ & 6月24日 & 入 \\
\hline 107 & 踊場手摺 & トガ & $6 !$ & $3 !$ & $1: 5$ & & $1 \dot{T}$ & 6月24日 & $\lambda$ \\
\hline 108 & 中敷鴨椐 & トガ & $\begin{array}{l}1 \\
6 !\end{array}$ & 31 & $\begin{array}{ll}1 & 5\end{array}$ & & $5 \mathrm{~T}$ & 6月24日 & $\lambda$ \\
\hline 109 & 上立柱 & 七ノキ & $10 !$ & 3寸3分 & 角 & & 3 本 & 6 月24日 & \\
\hline 115 & 勝手手洗枠 & 赤杉 & $6 !$ & 217 & 11 & & 3 枚 & 6月24日 & 1本 \\
\hline 116 & 勝手手洗枠 & 赤杉 & $\begin{array}{lll}3 & 3 \\
3\end{array}$ & & 11 & & $1 \mathrm{~T}$ & 6月24日 & $\lambda$ \\
\hline 91 & 炭入アリザン & 上ノキ & $\begin{array}{ll}1 & 1 \\
1 & 1\end{array}$ & 讨角 & & & 8 本 & & \\
\hline 79 & 掛サヤ & マツ & $7: 5$ & $\begin{array}{ll}11 & 8\end{array}$ & 17 & & 1 本 & & \\
\hline 81 & 戸袋血 & マッ & $\begin{array}{l:l}3 & 2\end{array}$ & $\begin{array}{l:l}1 & 8 \\
\end{array}$ & & & 1 本 & & \\
\hline 65 & ハサミ敷 & マッ & $4 !$ & 1 & & & 1 本 & & \\
\hline
\end{tabular}

表注 : 網掛け部分は表 1 と異なる箇所を示す。上から番号順ではなく史料に 記される順にまとめた。備考欄は余白の記載内容。
表 3 樹種が異なるもの

\begin{tabular}{|c|c|c|c|}
\hline 番号 & 田梌 & & \\
\hline 鱼 万 & 用还 & 見積書 & 用材調書 \\
\hline 65 & 勝手入口挟敷用 & 赤松 & マツ \\
\hline 71 & 勝手床カクレ用 & 松 & 赤松 \\
\hline 72 & 勝手袋天板用 & $\begin{array}{l}\text { 松 㚈 } \\
\text { 又心、ト }\end{array}$ & トチ \\
\hline 86 & 水遺梥中ジキ & 杉 & 赤杉 \\
\hline 90 & 水遺炭入クレ用 & 松 & 赤松 \\
\hline 98 & 水遺道具柵用 & 杉 & 赤杉 \\
\hline 100 & 水遺道具柵栈 & 杉 & 赤杉 \\
\hline 101 & 水遺茶碗柵用 & 杉 & 赤杉 \\
\hline 105 & 二階踊場無目 & 松 & 赤松 \\
\hline \begin{tabular}{|l|l|}
115 \\
\end{tabular} & 勝手手洗便所入口 & 杉 & 赤杉 \\
\hline & & 杉 & \\
\hline
\end{tabular}

表 4 長さが異なるもの

\begin{tabular}{|c|c|c|c|}
\hline 番号 & 用途 & $\begin{array}{c}\text { 長さ(単 } \\
\text { 列 }\end{array}$ & 位:尺) \\
\hline & 腰掛框用 & 9 & 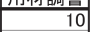 \\
\hline & 腰掛クレ用 & 9 & 10 \\
\hline 32 & 床板用 & 6 & \\
\hline 37 & 二ジリ敷用 & 6 & 1 \\
\hline 38 & 二ジリ中敷鴨居 & 6 & 10 \\
\hline 45 & 茶道口敷用 & 9 & \\
\hline 57 & 席天并廻用 & 9 & \\
\hline 58 & 席天井笔用 & 9 & 10 \\
\hline 67 & 勝手入口戸當リ用 & 9 & \\
\hline 71 & 勝手床カクレ用 & 9 & \\
\hline 74 & 勝手押入敷用 & 9 & \\
\hline 76 & 水遺水ハリロシキ & 9 & 10 \\
\hline 85 & 水遺中柱 & 9 & \\
\hline 109 & 三階上立柱用 & 9 & 1 \\
\hline
\end{tabular}

表 $3 \cdot 4$ 注 : 用途名は『見積書』に倣った。
と「一本」は鉛筆書きである。また、「入」と「一本」は、「積残リ」 と同じ余白に記されていることから史料作成後に追記されたもので あろう。これは鉛筆書きとインク書きの違いと整合的である。「積残 リ」と 2 重線で抹消していること、「入」や「一本」の追記を勘案す ると、新たに調達の必要がなかった部材を「積残リ」とし、「入」や 「一本」は、新たに調達された際に記入したものと推測される。つま り『用材調書』には新たに調達する必要がある部材が記された。これ は、前記した『見積書』と『用材調書』における数量の相違とも整合 的である。『用材調書』に記す番号 31 腰掛榑板の数量が、『見積書』 に記された数量よりも板目 3 枚分少ないのは、新たに調達寸る必要が なかったため、記されなかったと考えられるのである。しかしながら、

「入」「一本」の記載が一部に限られ、また「積残リ」の記載は 1 箇 所のみであり、詳細は明らかでない。

用材の調達は材木業者であるとすると、『用材調書』は材木業者が 『見積書』をもとに作成したものと推測される。これは内容的にも、 また筆跡が傳兵衛以外という事実とも整合的である。

なお『用材調書』が収められていた前記した封筒と、『用材調書』

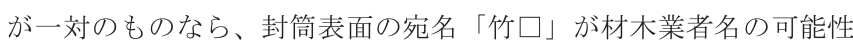
もあるが、これも詳細は明らかでない注 12)。

\section{3. 用材計画の分析}

第 2 節で『見積書』と『用材調書』の関係について推論した。用 材計画の分析ではこれをふまえ、『見積書』を中心に、『用材調書』 はこれを補完する史料として用いる注 13 。

『見積書』に記載のある通し番号 1 から 122 までの 122 項目のうち、 通し番号 113 の茶席天井用の臀材と 114 の藤ツル (表 1 参照) を除く 計 120 項目の部材、寸なわち丸太や角材等 231 点と板材 136 点、 24 坪について分析する。

\section{3-1 樹種と使用箇所}

用材は杉を主体とし、松、栗、檜、栂、杤の計 6 種を用いている。 部材ごとに樹種の割合を示すと図 3 のようになる。

杉材は柱や桁などの構造部材あるいは、母屋や小屋束、垂木、隅 木といった小屋組の部材、さらには鴨居・廻縁・竿縁にも用いられ ている。また板材の多くは杉であることが確認できる。松は敷居、 寄敷、無目など構造耐力の必要な箇所のほか、榑板や階段の段板、 側板にも使われている。栗は梁の 2 点のみである。檜は柱の一部に 見られるほか、梁や足固め、根太掛を含む根太、栈、胴縁など、お もに構造を補強する部材に用いられている。栂は敷居と鴨居や、手 摺に、杤は袋天板に使われている。

同一の部材であっても複数の樹種が用いられているのが留意され る。柱・梁・框・敷居・鴨居・栈・造作材（板材除く）であり（図 3 参照）、部材ごとに用途と樹種をみると表 5 のようになる。樹種の使 い分けはどのようになされているのか検証する。

まず柱材は杉・松・檜である。多くは杉だが (図 3 参照)、松は床 柱、檜は二階の柱に用いられていることがわかる（表 5 参照）。床柱 を除くと、階数で使い分けされている。同様に他の部材についてみ ると、梁材では栗が妻梁に、檜が陸梁に用いられている。見えがか りとなる妻梁には栗が、陸梁は小屋組を支えるため耐力のある檜が 選ばれたのだろう。框材では、松が腰掛に、杉は水屋の道具棚に使 われている。松は水湿等に耐えるため外部の腰掛（図 2 参照）に選 
ばれている。敷居は中敷居を除くと、挟敷居を含むすべてが松であ る。いっぽう鴨居は杉だが、二階の中鴨居は栂である（表 5 の網掛 け部分参照)。栈は水屋の蟻栈には檜、水屋の道具棚には杉が用いら れている。水屋の蟻栈は流し筫子板を支えるため、耐久性に優れた 檜である。造作材には、二階手摺は栂だが、その他の手洗・便所の 入口枠は杉である。二階は子供室で内向きの居室であり栂が選ばれ たのであろう。

このように樹種は単に使用箇所によって画一的に選ばれるのでは なく、階数や場所・用途に応じて、より相応しい選択がなされてい

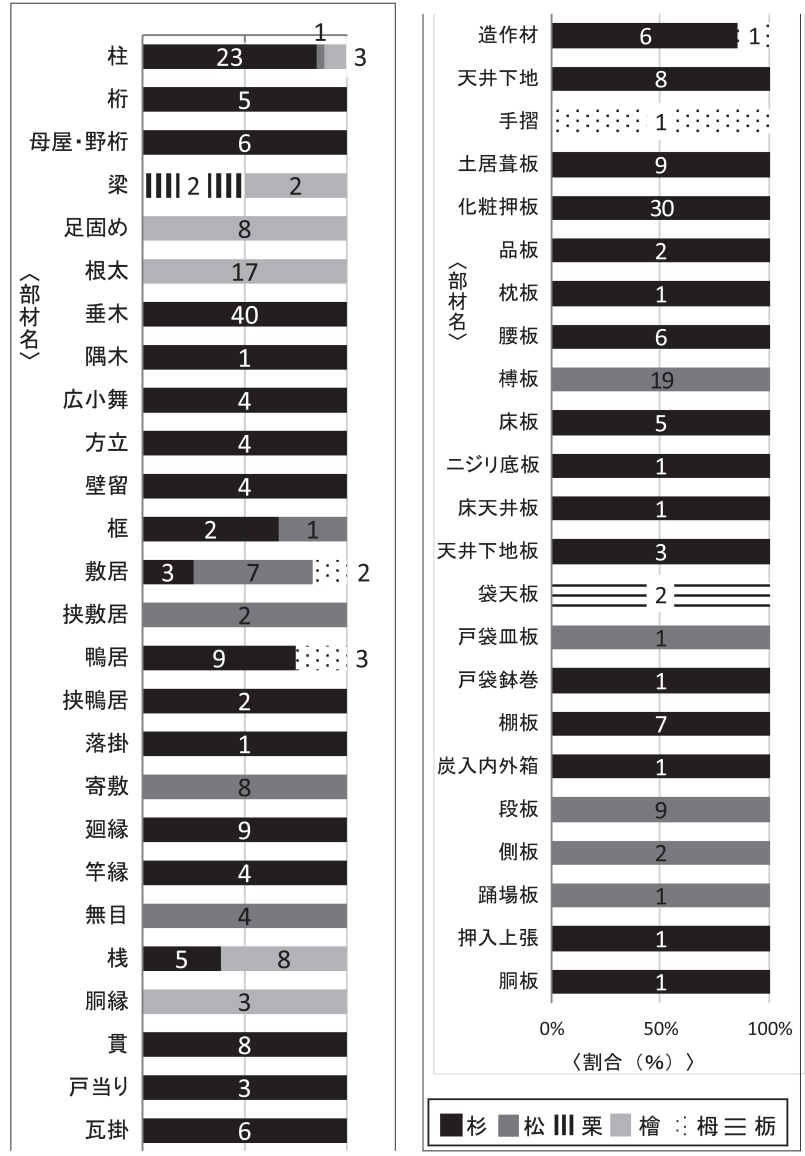

図 3 部材ごとにみる樹種の割合

注 : 母屋・野桁は小屋束を含み、根太は根太掛を含む。（図 4 も同様） 造作材と天井下地は板材を除く。

表 5 樹種の使い分け

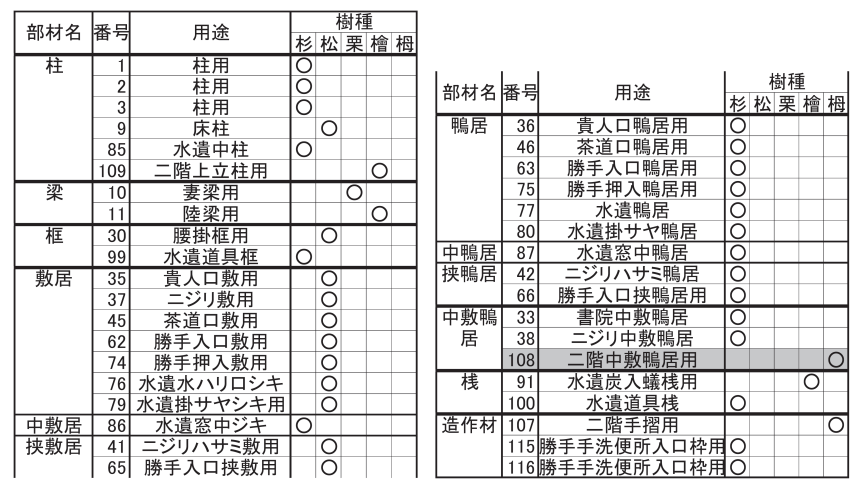

表注 : 番号と用途名は『見積書』に対応している。
たことが確認できる。

\section{3-2 品質}

品質の分類は 3 種からなる。すなわち、(1)等級、(2)木理、(3)等級 と木理を併記、の 3 種である。それぞれについて『見積書』での表記 を挙げると、(1)は「上・中・並上・並・下」、(2) は中杢・柾・平柾・ ソバ柾・小節注 14)・無ジ注 15)」、(3)は上ソバ柾・中ソバ柾・上中 圭・中柾」である。

部材を上記(1)〜 (3)の 3 種の品質種別にわけ、場所ごとに整理した のが表 6〜8 である注 16)。表 6 は(1)の等級、表 7 は(2)の木理、表 8 は (3)の等級と木理を併記したものである。またここにいう場所とは、 全体注 ${ }^{17}$ ) のほか、一階の茶席・水屋・勝手口付近 (手洗・便所含 む) ・階段・二階四畳半(押入れ含む) ・外部の計 6 か所である(図 2 参照)。

表 6 にある通り、柱や梁・桁などを含む軸組材、母屋や小屋束・ 垂木などを含む小屋組そして、根太を含む床組については、品質が 等級によって示されていることがわかる。丸太材の品質はいずれも 等級によって表されている（表 6 参照）。丸太材では、木理の表記は なされていない。「皮付」や「名グリ」は品質ではなく品名欄に樹種 と併記され（表 1 参照）、上記 3 種の品質と区別していることがわか る。

茶席については多くの部材が表 7 にあって、品質が木理によって 示される部材の多いことがわかる。これに加えて表 7 の茶席におけ る部材は、品質欄に記号の描きこみが多い（表 7 の網掛け部分）。 表 8 の等級と木理を併記する部材は、表 6 や表 7 に比べて少ない。 茶席だけをみると表 7 の木理を示寸部材についでその数は多いが、 書院や躍口の中敷居・中鴨居（連子空の中敷居と中鴨居）などに限ら れる。階段や二階、外部の部材にはないことがわかる。

表 6 等級を示す部材を場所ごとにみる

\begin{tabular}{|c|c|c|c|c|c|c|}
\hline \multicolumn{2}{|c|}{\begin{tabular}{|l|} 
階数 場所 \\
\end{tabular}} & \multicolumn{5}{|c|}{ 部材名 } \\
\hline & \multirow{4}{*}{ 全体 } & $\langle$ 〈柱〉 & $\langle\langle$ 軒桁〉 & $\langle$ 出桁〉 & $\langle$ 〈母屋〉 & \\
\hline & & 〈陸梁〉 & 足固 & & 〈床根太〉 & 根太掛 \\
\hline & & 小根太 & 〈野桁小屋束〉 & 〈軒垂木〉 & 〈隅木〉 & 野垂木 \\
\hline & & 土居葺 & 廣小舞 & 化粧押 & 野地及壁貫 & 熍板 \\
\hline \multirow{10}{*}{ 一階 } & 茶席 & $\frac{\text { 眮掛 }}{\text { 井下地 }}$ & $\frac{\text { 力置 }}{\langle\text { 样〉 }}$ & & & \\
\hline & \multirow{4}{*}{ 水屋 } & 無目 & 〈中柱〉 & 寄敷 & 鞘欄間の敷居 & 鞘欄間の鴨居 \\
\hline & & 水張口の敷居 & 水張口の鴨居 & 水張口の方立 & 戸袋の皿板 & 户袋鉢巻 \\
\hline & & 悹の中敷居 & 空の中鴨居 & 炉板 & 炭入の榑板 & 炭入の蟻栈 \\
\hline & & 炭入内外箱 & 棚框 & 棚棧 & & \\
\hline & & 勝手口の敷居 & 勝手口の鴨居 & 勝手口の方立 & 勝手口の挟敷居 & 勝手口の挟鴨居 \\
\hline & \multirow{3}{*}{$\begin{array}{l}\text { 勝手口 } \\
\text { 付近 }\end{array}$} & 床榑板 & 胴縁 & 簀負 & \multirow{3}{*}{$\begin{array}{l}\text { 手洗·便所の入口 } \\
\text { 押入の鴨居 }\end{array}$} & \\
\hline & & 袋天板 & 棚板 & 押入の敷居 & & \\
\hline & & 上り口の段板 & 上り口の無目 & 上りロの蹴込板 & & \\
\hline & 階段 & $\begin{array}{l}\text { 段板 } \\
\text { 路込板 }\end{array}$ & 側板 & 踊場の無目 & 踊場板 & 手摺 \\
\hline 三階 & 四畳半 & 中敷居 & 中鴨居 & 胴板 & 押入上張 & \\
\hline & 外部 & 喓掛框 & & & & \\
\hline
\end{tabular}

表注：〈〉付きの部材は丸太材を示す。網掛け部分は、品質欄に記号の 描きこみがあるものを示す。（表 7 も同様）

表 7 木理を示す部材を場所ごとにみる

\begin{tabular}{|c|c|c|c|c|c|c|}
\hline \multicolumn{2}{|c|}{ 階数 場所 } & \multicolumn{5}{|c|}{ 部材名 } \\
\hline 一階 & 茶席 & $\begin{array}{l}\text { 書院の枕板 } \\
\text { 連子空の貫 } \\
\text { 茶席の天井廻縁 }\end{array}$ & $\begin{array}{l}\text { 貴人口の敷居 } \\
\text { 連子空の底板 } \\
\text { 茶席の天井竿縁 }\end{array}$ & $\begin{array}{l}\text { 㘗口の敷居 } \\
\text { 茶道口の敷居 } \\
\text { 奇敷 }\end{array}$ & 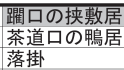 & $\begin{array}{l}\text { 躍口の挟鴨居 } \\
\text { 茶道口の方立 } \\
\text { 床の間天井迴縁 }\end{array}$ \\
\hline & 水屋 & 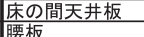 & 诵棚板 & 鱼棚板 & 道具棚板 & \\
\hline 三階 & 四畳半 & 柱 & & & & \\
\hline 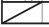 & 外部 & 永屋外横の腰板 & 腰掛の榑板 & & & \\
\hline
\end{tabular}

表 8 等級と木理を併記し示す部材を場所ごとにみる

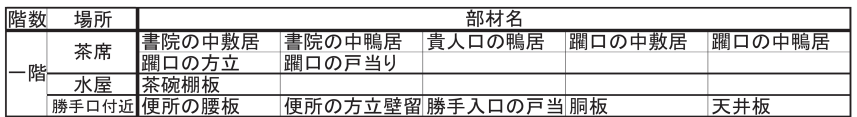




\section{3-2-1＼cjkstart造作材の品質}

部材の中でその数が多いのは造作材である。造作材は使用箇所によ って品質の扱いにおいてどのように差異化されたのであろうか。

ここで考察の対象とする造作材は、場所別に比較し検証可能な程度 の数があるものに限定する。具体的には方立・戸当り・敷居・鴨居・ 挟敷居・挟鴨居である。造作材を場所ごとに分け、品質を示した（表 9) 。

水屋・勝手口付近 (手洗・便所含む) -二階四畳半(押入れ含む)は、 「中」の品質のものが多いことがわかる。一方、一階の茶席は、等 級と木理を併記するものが多い。また茶席の等級は、他の場所が「中」 に対し「上」のものが多い。茶席の造作材に限ると、他の場所に比 べて等級が高く（後述 3-2-3）、また木理を示したものが多い。また 前記したように木理とともに記号によって品質を示すものが多い。 茶席は水屋・勝手口付近 (手洗・便所含む) -二階四畳半(押入れ含む) に比べて、より細かく部材計画がなされていることがわかる。茶席 に最も上質の空間を求めるという一般的な指向性が、『中野家文書』 という史料を通してうかがえるのである。

\section{3-2-2＼cjkstart記号の描きこみについて}

品質表示における記号の描きこみについて検証する。品板・貴人 口の敷居 - 䠰口の挟敷居 - 床の閒天井廻縁 - 茶席の天井廻縁・茶席 の天井竿縁の部材には、『見積書』の品質欄に等級や木理とともに記 号の描きこみがある (表 6 ・表 7 の網掛け部分参照)。品板以外はす べて茶席に関する部材である。また品板を除くすべての品質欄に 「柾」とあり、その字の前に記号が描きこまれる。これをまとめた のが表 10 である。なお表 10 の「品質欄」は『見積書』の品質欄か らの抜粋である。

品板以外の部材に共通して記される木理の「柾」について考察す る。品質欄に記号の描きこみがなく、木理のみが記入されているも のに「平柾」や「ソバ柾」がある注18)。木理の柾を示すとともに、「平」・ 「傍」によって柾目がある部材の面を特定している。これと同様に、 描きこまれた記号は「平」「傍（ソバ）」のように、木理のある部材 の面を示したものと推測される。

表 10 の番号 4 ・ 5 に記される記号は同一のものである。また木理 も同じ「柾」であるため、このふたつの部材の品質は同一であるこ

表 9 場所別にみる造作材の品質

\begin{tabular}{|c|c|c|c|c|c|c|c|}
\hline 階数 & 場所 & 方立 & 戸当り & 敷居 (中敷居) & 鴨居(中鴨居 & 挟敷居 & 挟鴨居 \\
\hline \multirow{4}{*}{ 茶席 } & 貴人口 & & & 柾 & 上ソバ柾 & & \\
\hline & 躍口 & 上ソバ柾 & 上ソバ柾 & 平柾 & 上ソバ柾 & 柾 & ソバ柾 \\
\hline & 書院 & & & (上ソバ柾) & (上ソバ柾) & & \\
\hline & 茶道口 & ソバ柾 & & 平柾 & ツバ柾 & & \\
\hline \multirow{3}{*}{ 一階 水屋 } & 水張口 & 中 & & 中 & 中 & & \\
\hline & 欄間 & & & 中 & 中 & & \\
\hline & 空 & & & (中) & (中) & & \\
\hline \multirow{3}{*}{\begin{tabular}{|l|}
$\mid \begin{array}{l}\text { 勝手口 } \\
\text { 付近 }\end{array}$ \\
-階四畕半
\end{tabular}} & 手洗·便所 & 中 & & & & & \\
\hline & $\begin{array}{l}\text { 勝手口 } \\
\text { 押入 }\end{array}$ & 中 & 中ソバ柾 & 中 & 中 & 中 & 中 \\
\hline & & & & (中) & (中) & & \\
\hline
\end{tabular}

表 10 品質欄にある記号の描きこみ

\begin{tabular}{|c|c|c|c|}
\hline 部材名 & 記号 & \begin{tabular}{|c|} 
木理· \\
等級
\end{tabular} & 品質欄 \\
\hline 1 品板 & アルファベットのしに似ている & 上 & $L I$ \\
\hline 2 貴人口の敷居 & アルファベットのLを回転 & 柾 & ᄀ极 \\
\hline 3 躙口の挟敷居 & アルファベットのLを回転 & 柾 & 7 机 \\
\hline \begin{tabular}{l|l|l|}
4 & 床の間天井廻縁
\end{tabular} & アルファベットのしに似ている & 柾 & $L_{12}$ \\
\hline 5 茶席の天井廻縁 & |アルファベットのLに似ている & 柾 & L杞 \\
\hline \begin{tabular}{l|l}
6 & 茶席の天井竿縁
\end{tabular} & カタカナのコの字を回転 & 柾 & U打 \\
\hline
\end{tabular}

とがわかる。つまり床の間天井廻縁 (番号 4) と茶席の天井廻縁 (番号 5)には同じ品質のものが使われている。

茶席の天井竿縁の品質欄にある描きこみに注目する（番号 6 の品 質欄参照)。記号から引き出し線で「柾」と記す。中野家住宅の茶席 の天井の竿縁は、見えがかり部分の二面のうち、下面は柾目だが 側面は柾目でないことが遺構から確認できる。そこで茶席の天井竿 縁に記される記号と木理による品質の表記は、下面の一面のみを柾 目とすることを示すものであることがわかる注 19)。

貴人口の敷居 ・ 躍口の挟敷居 - 床の間天井廻縁・茶席の天井廻縁 ・ 茶席の天井竿縁については、記号によって柾目の面を厳密に指示し た（表 11 参照）。指示の対象は材木業者か、あるいは配下の大工な のか詳細は不明であるが、傳兵衛は記号を用いることで、的確な木 取りの指示を図ったのであろう。木理に関する細やかな用材計画が 見積もりの段階でなされているのである。

このような傳兵衛の木理への強いこだわりを裏打ちするのは、腰 掛の榑板である (表 1 の番号 31 、図 2 参照)。『見積書』に柾目 3 枚 と板目 3 枚の計 6 枚とある榑板は現況のそれと一致するところであ るが、6 枚の板は柾目と板目が交互に規則的に配置されている。こ れによって木理自体が優れた意匠性を発揮している（写真 3 )。

\section{3-2-3 等級}

用材の等級による品質表示は、「上・中・並上・並・下」の 5 種で ある。板材を除いて角材や丸太の材計 222 点を等級分けし注 20)、部 材ごとに等級の割合をみたのが図 4 である。図 4 の「その他」とは、 5 種の等級以外の、木理等による品質表示によるものをまとめたも のである。

まず「中」と「並」の等級の優劣について検討しておく。番号 1 の柱材の品質は「上」「中」と記され、他の柱材（番号 2 と 3 ）が「上」 となっている (表 1 参照)。同じ柱として用いられる用材の品質に大 きな差異があるとは考えにくいことから、「中」は「上」の次の等級 に位置づけられるものと推測される。つまり 5 種は、上位から「上・ 中・並上・並・下」の 5 段階である。

内訳をみると、「上」の材は 66 点、「中」の材は 49 点、「並上」の

表 11 品質欄の記号より考えられる部材断面

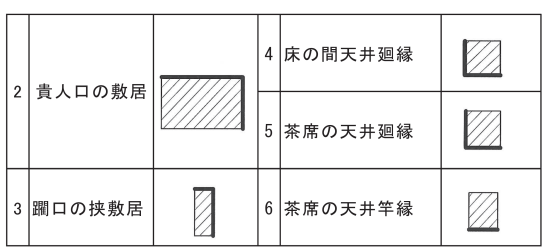

表注:番号は表 10 に対応。 太線は、記号が示す 面、すなわち柾目と する面。

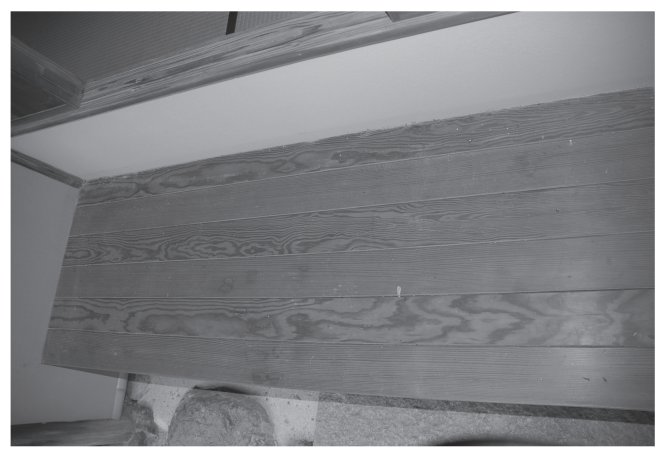

写真 3 中野家住宅茶室「皎庵」の腰掛 
材は無く、「並」は 58 点、「下」の材は 4 点、その他は 45 点である。 「上」が最も多く、「上」の材が多用されたことがわかる。「下」の 材は数の上では最も少なく、一部の使用に留まる。

「上・中・並上・並・下」の 5 段階の等級がどのように使い分け されたのかをみる（図 4)。まず「上」の材は、柱・桁・垂木・隅木・ 広小舞・框・栈である。これに対して「並」は、母屋・野桁・小屋 束・梁・足固め・根太・胴縁・貫 ・瓦掛 - 天井下地など、見え隠れ の部材が多い。そして「下」の材は、母屋・軒桁・小屋束であり、 その用途はおもに小屋組であった。等級による使用箇所の使い分け が明確になされているのである。これは大工の作事として、あるい は一般的なことともいえるが、傳兵衛も例外なくそのように作事し ていたことが確認されるのである。

\section{3-3 価格}

見積価格より茶席と水屋の坪単価を検討する注 21 。茶席の坪単価 は 6,976 円であり、いっぽう水屋は 7,784 円となる注22)。茶席に比 べ水屋が高額である。水屋は茶席に比べ、単価 500 円以上の用材が 多いことが確認できる（表 12）。水屋の最も高額な用材は、茶碗棚 の板材 3 点と通棚の板材 1 点である。いずれも単価 2, 000 円である。 茶席に比べ水屋の坪単価が高いのは、単価の高い板材が多く用いら れていることに要因のひとつがあるのではないかと考えられる。

さらに用材の数量と単価について、場所ごとに検討する。費用は用 材の単価とその数量によって規定されるものと考えられるからであ
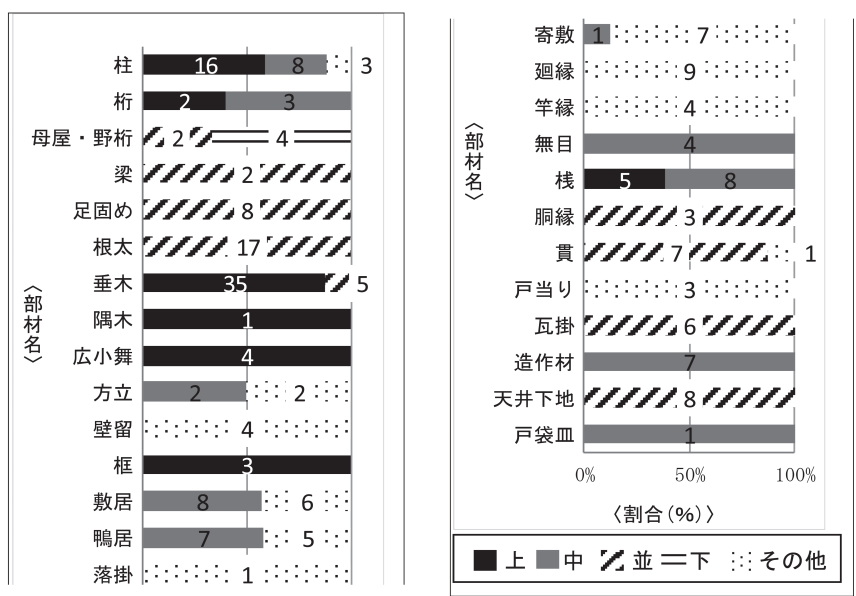

図 4 部材ごとにみる等級の割合

表 12 場所ごとに用材の数量を単価の価格別にみる

\begin{tabular}{|c|c|c|c|c|c|c|c|}
\hline 場所 & $\sim 50$ & 500 & $\begin{array}{r}\text { 用材の眘 } \\
1.000 \sim 1.500\end{array}$ & $\begin{array}{l}\text { 单価(用) } \\
1.500 \sim 2.00\end{array}$ & $2.000 \sim 2.500$ & $2.500 \sim$ & 合計 \\
\hline 全体 & 163点、9坪 & 27 点、5坪 & 3点 & 1 点 & & & 194 点、14坪 \\
\hline $\begin{array}{l}\text { 茶席 } \\
\text { 水屋 }\end{array}$ & $\begin{array}{l}36 \text { 点、3坪 } \\
29 \text { 点 }\end{array}$ & $\begin{array}{r}3 \text { 点 } \\
6 \text { 6点 }\end{array}$ & $\begin{array}{l}1 \text { 点 } \\
3 \text { 点 }\end{array}$ & 1点 & 4 点 & 2点 & $\begin{array}{l}42 \text { 点. } 3 \text { 坪 } \\
43 \text { 点、1 } 1 \text { 坪 }\end{array}$ \\
\hline 勝手口付近 & 39 & 2点 & 3 & $\begin{aligned} 2.5 \text { 坪 } \\
2 \text { 占 }\end{aligned}$ & & & $\begin{array}{l}44 \text { 点. } 2 . \\
17 \text { 占 }\end{array}$ \\
\hline 二階四鲾半 & 8 点、1束 & 11坪 & & & & & \\
\hline $\begin{array}{l}\text { 外部 } \\
\text { ₹の他 }\end{array}$ & 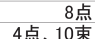 & $\begin{array}{c}\text { 1点 } \\
10 \text { 占 }\end{array}$ & & & & & $\begin{array}{l}9 \text { 吕 } \\
4 \text { 点、 }\end{array}$ \\
\hline
\end{tabular}

表注：500〜1,000 は 500 円以上 1,000 円未満を示寸。（他の価格帯も同様）

「その他」には場所が判明しないものと、分析対象外とした番号 113 ・ 114 の用材を含めた。

表 13 価格を比較

\begin{tabular}{|c|c|c|c|c|c|c|}
\hline 番号 & $\begin{array}{c}\text { 樹種 } \\
\end{array}$ & 長さ×幅 & 厚さ & 品質 & 数量 & 価格 (円) \\
\hline 111 二階胴板用 & 杉 & 6 尺 $\times 8$ 寸 & 2分5厘 & 並上 & 1束 (2.5坪) & 450 \\
\hline 119|勝手胴板及天井 & 杉 & 6 尺 $\times 6$ 寸 & 2分5厘 & 中柾 & 2.5 坪 & 4,500 \\
\hline
\end{tabular}

表注 : 番号と用途名は『見積書』による。（表 1 参照）
る。場所ごとの用材の数量を単価別に示したのが表 12 である。2,500 円以上の単価の用材は茶席の 2 点のみである。2 点とは床柱と床の 間天井板であり、それらが最も高額であることがわかる（表 12 の網 掛け部分参照）。床柱は赤松皮付丸太、床の間天井板は赤杉中杢であ った。いっぽう二階四畳半や外部などでは 1,000 円以上の単価の用 材は見当たらない。これは部屋の性格から首肯できるところである。

用材の価格はその品質や大きさによることが予想される。このう ち品質に関して確認するため、樹種が同じで大きさもほぼ等しい胴 板について価格を比較した（表 13）。これによると価格の差は「中 柾」「並上」という品質（等級、木理）によって著しく格差のあるこ とがわかる。大きさに応じた見積価格の差異は当然として、用材の 品質が見積価格に大きく影響したことがあらためて確認できるので ある。

4. おわりに

中野家住宅とくに茶室「皎庵」の作事にあたって見積もり用に傳 兵衛が作成した『見積書』を中心に、また『用材調書』によって補 完しつつ、傳兵衛の作事の実態、用材計画のあり方について検討し た。以下にその概要をまとめる。

(1)樹種により使用箇所の使い分けがなされている。

(2)同一の部材でも階数や場所、用途によって樹種の使い分けがな されている。

(3)造作材の品質では、水屋・勝手口付近・二階の室に比べて茶席 が、最も細かく部材計画されている。

(4)木理に関する細やかな用材計画が見積もりの段階でなされ、そ れが実際の建築にすぐれた意匠として活かされている。

(5)等級による用材の使用箇所の使い分けが明確になされている。

(6)茶席には相対的に高額な用材が用いられている。それは用材のと

くに品質を反映するものと推測される。

以上、中野家住宅の茶室を通して北村傳兵衛の作事の一端を明ら かにした。傳兵衛は見積もり段階から綿密な用材計画を企図し、ま た変更を適宜加えて施工実施にのぞんでいたことが、作事関係史料で ある『中野家文書』によってあらためて確認された。

本稿では、傳兵衛が手がけた作事のごく一部を垣間見たに過ぎな い。それが傳兵衛の活動全体の中でいかなる位置を占めるのか。さ らには同時代に活躍した近代における町屋大工あるいは数寄屋大工 の一人として傳兵衛はどのように評価されるのか注 23$)$ 。本稿では触 れなかったが、近代京都の工匠として和風建築に大きな足跡を遺し た傳兵衛はまた建築家藤井厚二から影響をうけたことが中野家住宅 を通してうかがえるということもある ${ }^{2)}$

本稿で注目した、傳兵衛の作事に関する一級の希少な史料『中野家 文書』について、さらに詳細な分析と検討を加えることが必要である 注 24)。それをふまえて、作事史料全体からうかがえる内容が中野家住 宅の遺構としていかに反映されているのかを分析すること、そして傳 兵衛が作事した他の作品へと考察対象を拡げることが今後必要であ り、究明すべき残された課題は少なくない。

\section{謝辞}

建造物の詳細調査および『中野家文書』の調査に際して、中野家 の現当主中野康男氏をはじめ中野家の皆様には格別のご配慮をいた 
だいた。また中尾秀正氏、百瀬ちどり氏をはじめ長岡京市教育委員 会の方々にご協力いただいた。さらに北村傳兵衛に関連する資料調 查で中村昌生氏に便宜をはかっていただいた。ここに深謝する次第 である。

\section{注}

注 1）傳兵衛やその作品に関して、参考文献 1 のほかに参考文献 4 ～12 が挙 げられる。中野家住宅の茶室については参考文献 4 が現況の茶室の写 真とともに『中野家文書』の一部を掲載する。傳兵衛による作品紹介 として参考文献 $5 \cdot 6$ がある。他に北村傳兵衛家に関する史料として『北 村（伝）家文書』が京都市歴史資料館に計 40 点所蔵される。この中に 大工職関連の史料が 8 点程度含まれるが、宝暦年間から明治初頭頃の 普請願書等であって、傳兵衛以前の史料に属する（参考文献 15）。

注 2）中野家住宅は平成 19 年度から実施された京都府近代和風建築総合調查 の対象に挙げられており、一次調查（関西大学建築史研究室担当）の 所見では二次調査の候補物件として推萀された。しかし二次調查の対 象とはならず、そのため近代和風建築として詳細な建物調查はなされ なかった (参考文献 14)。その後、平成 21 年の同研究室による詳細調 查の結果を踏まえ、主屋・土蔵・茶室は平成 22 年に国の登録有形文化 財に登録された。

注 3）前掲注 2 の関西大学建築史研究室による平成 21 年の調查で『中野家文 書』の全 59 点を確認した。中野家の私的な 3 点を除いて、差出人が不 明確なものもあわせて、傳兵衛が中野家の増改築に携わった際の史料 である（参考文献 2 参照）。

注 4）北村傳兵衛による作事の沿革については、『中野家文書』の『中野邸 數咅屋設計図』、『写真帳』冒頭の「調子中野邸工事概要」による。

注 5) 岡田信子ほか校訂『京都御役所向大概覚書』(『清文堂史料叢書第 5 ・ 6 刊』)、清文堂出版、1973 年による。京都町奉行所が近世初期より 中期にかけての京都を中心とした直轄地全体を把握するために作成 したもの。

注 6) 『調子八郎家文書』所収の史料。調子家所蔵、京都府立山城郷土資料 館寄託。本稿は長岡京市文化財倸の写真帳による。なお調子氏は中世 に遡り、近世には調子村に 70 石を領した。本史料は同氏の支配領地 を記し、天明 4 年書写本を明治 3 年に筆写したもの。

注 7） 中野家は北村家と親戚関係にあり、先代の傳兵衛と中野家は交流があっ た（参考文献 4) 。工匠傳兵衛は組合等には属さなかったものの、先代 傳兵衛の代から施主との付き合いは継続していて、また中野家のよう に親族・知人からの依頼で作事を引き受けることがあった。中野家は 高島屋工作所（昭和 14 年設立）を出入り業者として家屋の維持に随時 つとめる中、同所を通じて建築家村野藤吾とも親交があった。主屋座 敷には村野のデザインによる応接ソファが現存する。工匠傳兵衛との 接点には互いに親戚関係にあったことに加え、普請そして建築への同 家の強い興味と関心がその背後にあったものと想像される。

注 8）安井圭工務店によるもの。参考文献 4 によると、この修復では化粧軒 廻り、屋根瓦莫き替え、柱の根継ぎ、対ずごね壁の全面塗り替え、天 井の臀の網代などがなされた。

注 9）「寸法」とは、断面寸法のこと。

注 10）「価格」とは、単価 $\times$ 数量の計算式で求められる小計のこと。

注 11）前掲注 9 に同じ。

注 12）『京都実業界』博信社、1912 年に、材木商竹原孝吉（東木屋町松原上 ル）の記載がある。しかし「竹口」を「竹原」とは判別できない。

注 13) 『見積書』と『用材調書』で樹種等が異なる場合は、『見積書』から 『用材調書』に変更されたものと見なし、変更後すなわち『用材調書』 のそれを採用した。

注 14）「小節」とは小節材の略。

注 15)「無ジ」とは無節の意。

注 16）品質欄に記入がない番号 10 妻梁の品質は不明であるため、分析対象 から除外した。なぜ品質闌に記入されていないのかは不明（『見積書』 には「中」と記入し後に消した形跡がある) 。

注 17）全体とは一階・二階・外部に分類できない部材の場所の意。ここには 軸部・軒まわり・梁組・小屋組・床組の部材が含まれる。

注 18）『見積書』に記された通りに表記した。平柾は鴨居等の幅広表面部分 が柾目で、傍柾は幅の狭い方の面が柾目であることを示す（『建築大 辞典 第 2 版』彰国社、1993 年) 。

注 19）中野家住宅の茶室は平成 20 年に木材の腐食等があって修復している
（前掲注 8 参照）。しかしこれ以外に改築等はなく、茶席の天井竿縁 は、傳兵衛による作事のものが現況を留めていると判断される。

注 20）場所が判明しない番号 $27 \cdot 28 \cdot 29$ の部材は除外した。

注 21）用材のうち、構造材は茶席と水屋に分類できず、また茶席は傳兵衛に よる新設であるが、水屋は既存の躯体を利用した改造であるため、一 概に比較することはできない。ここでの考察対象は、したがって各室 の造作材に限る。分析対象から除外した番号 113 席天井の臀材は、見 積価格に反映させるため対象に追加した。

注 22）床面積は茶席が 2.92 坪、水屋が 2.75 坪である（建造物の詳細調查 $<$ 注 2 前掲>と国登録文化財申請時の測量値をもとに算出）。用材に関 する見積価格は茶席が 20,369 円、水屋が 21, 405 円である。

注 23）傳兵衛と同時代に活躍した数寄屋大工では、たとえば笛吹嘉一郎（明 治 31 年〜昭和 44 年) に関する研究がある（参考文献 13）。

注 24）本稿で考察した用材計画に関連して、『中野家文書』の中には用材の 調達方法を示寸史料は見当たらない。材木業者（あるいはその関係者） として「竹口」なる人物が関与していたが、詳細は不明である。中野 家住宅の茶室には軒裏の間垂木や、裏板の代わりに使われる割竹さら に、連子の竹、水屋の流し部分の簧子、棚の釣竹など、多用途に竹材 が用いられている。にもかかわらず『見積書』に竹材に関する記載は ない。『中野家文書』の『写真帳』にある傳兵衛自筆の工事概要によ ると、植木は新たに用意したものは一部のみで、住宅敷地内にあった ものを再利用したことや、踩踞等に必要な石もまた敷地内のそれを転 用したと記される。と寸ると竹材もまた自己調達した可能性がある。 明治から大正なので中野家住宅より時期はやや遡るが、博覧会や物産 陳列場からの施主の直接購入によって建材調達がなされることがあっ たという（参考文献 16）。当地はまた竹材を豊富に産出する地域であ ることもこの推測を補強しよう。

\section{参考文献}

1) 中村昌生 : 数寄の工匠, 淡交社, 1986 。

2）有住侑子, 藤田勝也：中野家住宅と北村傳兵衛旧邸, 日本建築学会近畿支 部研究報告集，第 51 号，pp. 897 900，2011.6。

3）中野種一郎翁傳, 鹿島研究所出版会, 1972。

4）安井清, 木原千利: 蘇生する北村伝兵衛の茶室「晈庵」, 住宅建築, 2009.1。

5）北村傳兵衛編：生空庵集，1939。

6) 建築写真類聚刊行会編輯: 建築写真類聚 7-21 数寄屋造の別荘, 洪洋社, 1933。

7）伊奈陶編：ina REPORT No. 20, 1979 （後に西澤文隆：西澤文隆の仕事第 3 巻 つくる, 鹿島出版会, 1988 に再録）

8）和風建築社編：和風建築 第 7 号，建築資料研究社，1982。

9）篠田銘木店:木, 篠田銘木)店, 1974.12 (後に伊藤ていじ監修: 聞き書き 日 本建築の手わざ 第 2 巻 数寄屋の職人, 平凡社, 1985 に所収。また一 部は、新建築，新建築社，1978. 6 臨時增刊号に所収）。 他の巻に、傳兵衛の茶室に関する研究等が揭載されたものや、対談等も収 録されたものもある（普請, 京都伝統建築技術協会に所収）。

10）伊藤ていじ，横山正監修：現代和風建築集 第 $I$ 巻 棟梁の時代 $I$, 講 談社, 1984。

11）中村昌生 : 京の座敷，駸々堂出版，1980。

12）和風建築社：和風建築シリーズ 床の間，建築資料研究社，1998。

13）日向進, 矢崎善太郎, 松本康隆 : 茶人木津宗詮と数寄屋大工笛吹嘉一 郎による茶室の研究一近代の茶室に関する研究一, 住宅総合研究所研究 年報, No. 30, pp. 239 250，2003。

14）京都府教育委員会編 : 京都府の近代和風建築一京都府近代和風建築総合 調查報告書, 2009。

15）史料 京都の歴史 第 12 巻 下京区，平凡社，pp. 124〜125，1981。

16）熊谷透, 日向進: 近代における鳥取県大山町所子の民家普請（2）建材の 調達について, 日本建築学会大会学術講演梗概集 (F-2 分冊) , pp. 547 $\sim 548,2009.8$ 。

(2011年11月 9 日原稿受理，2012年 3 月 12 日採用決定） 